UNIO - EU Law Journal. Vol. 3, No. 2, July 2017, pp 139-147.

®2017 Centre of Studies in European Union Law

School of Law - University of Minho

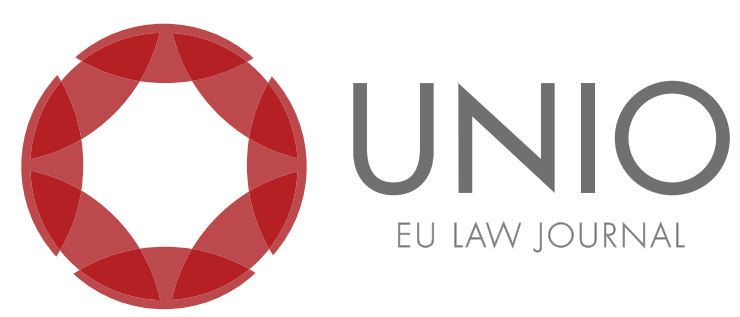

\title{
The right to withdraw the notification to leave the European Union under article 50 TEU: can we still save the marriage?
}

\author{
Mariana Alvim*
}

ABSTRACT: Article 50 TEU has caused considerable interest following its introduction in EU law, but mostly since the UK voted in favour of leaving the Union, a vote that provoked its first ever activation. However, this Article raises a few unanswered questions, such as if a Member State that formally notifies to the European Council of its intention to leave the EU, can it subsequently change its mind about this decision during the two-year period established in the Treaty. In the first part of the article, I intend to put the notification to leave the European Union under Article 50 of the TEU in perspective, elucidating the steps that have to be taken, and to address the silent aspects of Article 50. In the second Part, I will assess if a Member State that triggers Article 50 TEU, can still withdraw the notification to leave, once Article 50 TEU is completely soundless in this respect, and in doing so answer the central question of this article: "Can we still save the marriage?"

KEYWORDS: article 50 - withdraw - notification - European Union - Member State.

\footnotetext{
* PhD candidate at the University of Lisbon. Member of the Centre for Research in Public Law
} (CIDP) of the Law School of the University of Lisbon. 


\section{Introducation}

The right to withdraw from the European Union has been the object of a timeless quarrel. Some authors that stressed the supranational features of the European Union argued that any hypothetical right to withdraw was incompatible with the permanent and irreversible character of European integration, as reproduced in the general structure and in the specific provisions of the Treaties. ${ }^{1}$ The fact that the Treaties were concluded for an "unlimited period" was widely thought to exclude the right of unilateral withdrawal.

In its Opinion 1/91, the Court of Justice of the European Union (hereinafter, CJEU) clarified that apart from other International Agreements which merely create reciprocal rights and obligations and do not stipulate for a transfer of sovereign rights; "the EEC Treaty, albeit concluded in the form of an international agreement, none the less constitutes the constitutional charter of a Community based on the rule of law". ${ }^{3}$

In this context, the TEU has a dual legal character: it is an International Agreement in origin and, at the same time, a constitutional charter, which brings us to the conclusion that the European Union is a new and unique entity of International law.

And this duality implies that the interpretation of the European Treaties is governed, not only by European Union law, but also by International law namely the law of treaties.

Accordingly, some authors that were aware of the International law origins of the European Union accepted the possibility of withdrawal on the basis of the relevant rules of International law, but above all by common agreement of all Member States, as anticipated in Article 54 (b) of the Vienna Convention on the Law of the Treaties 1969. ${ }^{4}$

The German Federal Constitutional Court, in its decision on the ratification of the Maastricht Treaty 1992, anticipated the possibility of a Member State to withdraw from the Treaties even by way of a unilateral act. ${ }^{5}$

The Treaty Establishing a Constitution for Europe, that never came into force (the Draft Constitutional Treaty), recognized for the first time the power of a Member State to withdraw from the European Union.

However, as Article 59 of the Draft European Constitution demonstrates, this power was not an immediate or absolute one. ${ }^{6}$ Even though it was often said that Article 59 was quickly and not carefully drafted, the drafting process shows that it was extensively discussed. Proof of that is the fact that the text of the provision was changed substantially from the first ${ }^{7}$ to the final draft of the Constitution. ${ }^{8}$

\footnotetext{
${ }^{1}$ John A. Hill, "The European Economic Community: The Right of Member State Withdrawal", Georgia Journal of International and Comparative Law 12 (1982): 354.

${ }^{2}$ Both Articles 356 TFEU and 53 TEU state that the Treaties are "concluded for an unlimited period".

3 Opinion of the Court of Justice of 14 December 1991 delivered pursuant to the second subparagraph of Article 228 (1) of the Treaty- ECLI: EU:C:1991:490 [21].

${ }^{4}$ See Sara Berglund, "Prison or Voluntary Cooperation? The Possibility of Withdrawal from the European Union”, Scandinavian Political Studies 29 (June 2006): 150.

${ }^{5}$ Maastricht, BVerfGE 89, 155, page 190.

${ }^{6}$ See Raymond J. Friel, "Providing a Constitutional framework for withdrawal from the EU: Article 59 of the Draft European Constitution", ICLQ 53 (2004): 425.

7 See European Convention "Document from the Praesidium: Preliminary Draft Constitutional Treaty”, 28.10.02, CONV 369/02.

${ }^{8}$ See European Convention, "Draft Treaty establishing a Constitution for Europe", 18.07.2003, CONV 850/03.
} 
Thus, while the first draft did not contain any limitations on the withdrawing State's re-accession to the Union, two important provisions were added in the Constitution's final draft: first, that the two-year period for the negotiations could only be extended by unanimity, and second, that a Member State that decides to withdraw from the European Union would need to make a new application for accession should it wish to re-join the Union in the future.

It is interesting to note that the Praesidium considered that the right to withdraw from the European Union existed, even in the absence of an explicit provision to that effect, and could not be made conditional upon the conclusion of a withdrawal agreement.

Nevertheless, an agreement made between the Union and the Member State is always encouraged and the withdraw provision takes effect, in any event, two years after notification, not being in itself an obstacle for the withdrawal.

This Constitution's withdrawal clause was adopted a few years later and without any relevant changes by the Lisbon Intergovernmental Conference, becoming Article 50 TEU. $^{9}$

Article 50 has produced considerable academic interest, mostly since the United Kingdom voted in favour of leaving the European Union, a vote that precipitated its first ever activation. And as we will see ahead, the withdrawal process has been under intense scrutiny from the perspective of the United Kingdom's constitutional lawyers.

On 29 $9^{\text {th }}$ March 2017, the United Kingdom Prime Minister, Theresa May, has submitted notice to the President of the European Council, Donald Tusk, that her Country would be leaving the European Union under Article 50 TEU.

And once Article 50 TEU is triggered, the law of the European Union governs the withdrawal process, because only the decision to depart is taken in accordance with the Member State's domestic law, whereas EU law governs the departure itself.

And despite its rapid rise to fame following the 23 June 2016 referendum on British membership of the European Union, this sparsely worded provision raises more questions than answers. The withdrawal needs to be compliant with European Union constitutional law if the European Union is to preserve its character as a supranational order that creates rights and obligations for institutions, Member States and private persons.

Further, it should be borne in mind that the European Union's institutions and its Member States have limited instruments at their disposal to force other Member State to remain a member of the Union against its will, ${ }^{10}$ therefore if exit cannot be prevented, at least it can be regulated.

\section{The notification to leave the European Union in perspective}

Pursuant to Article 50 of the TEU, ${ }^{11}$ the withdrawal process begins when a

\footnotetext{
${ }^{9}$ Christophe Hillion, "Leaving the European Union, the Union way - a legal analysis of Article 50 TEU”, Swedish Institute for European Policy Analysis (August 2016):1-12.

${ }^{10}$ T.C. Hartley, Constitutional Problems of the European Union, (Oxford: Hart,1999),164-165.

${ }^{11}$ Article 50 TUE provides as follows: "1. Any Member State may decide to withdraw from the Union in accordance with its own constitutional requirements. 2. A Member State which decides to withdraw shall notify the European Council of its intention. In the light of the guidelines provided by the European Council, the Union shall negotiate and conclude an agreement with that State, setting out the arrangements for its withdrawal, taking account of the framework for its future relationship with the Union. That agreement shall be negotiated in accordance with
} 
Member State, having "decide[d] to withdraw from the Union in accordance with its own constitutional requirements", notifies the European Council "of its intention".

In fact, the authority of domestic constitutional requirements is based on the assumption that they conform to the general requirements of European Union Constitutional law, and particularly to the values enshrined in Article 2 TEU. ${ }^{12}$

Consequently, formal compliance with domestic constitutional requirements might not be sufficient to validate the initial withdrawal decision under Article 50 TEU if the correctness of such requirements is in doubt in relation to the respect of the EU standards.

Of course, the European Union would have no interest in preventing a Member State's departure if the latter's constitutional evolution disrespects the requirements of European Union membership, quite the contrary. Thus, Article 50(1) TEU provides the ability of Member States to withdraw from the EU legal order, but the success of any exit initiative depends not only on the Member's intention, but also on the fulfilment of the procedural and substantive requirements of Article 50 TEU, and on compliance with the rules and principles supporting the European Union legal order and that are under the control of the European Court of Justice.

If the notification were to be submitted without adequate legal authority, the European Council would arguably have to pause and wait for the CJEU's judgment, and/or obtain clarification of the validity of that notification before formally acknowledging receipt.

Moreover, Article 50 TEU stipulates that the notification has to come from the withdrawing State and must be submitted to the European Council.

It is important to acknowledge that Article 50 imposes only a few substantive and procedural conditions on the withdrawing Member State. Once it has given notice under Article 50(1) TEU in accordance with its own constitutional requirements, all that the withdrawing Member State is required to do, before the Treaties cease to apply, is to wait out the two-year period stipulated in Article 50(2) TEU. ${ }^{13}$

Consequently, it is not required to justify its decision to leave, nor does Article 50(2) TEU impose a duty upon it to negotiate and conclude a withdrawal agreement with the Union. ${ }^{14}$

At the most, the withdrawing Member State may be under an implied duty to

\footnotetext{
Article 218(3) of the Treaty on the Functioning of the European Union. It shall be concluded on behalf of the Union by the Council, acting by a qualified majority, after obtaining the consent of the European Parliament. 3. The Treaties shall cease to apply to the State in question from the date of entry into force of the withdrawal agreement or, failing that, two years after the notification referred to in paragraph 2, unless the European Council, in agreement with the Member State concerned, unanimously decides to extend this period. 4. For the purposes of paragraphs 2 and 3, the member of the European Council or of the Council representing the withdrawing Member State shall not participate in the discussions of the European Council or Council or in decisions concerning it. A qualified majority shall be defined in accordance with Article 238(3)(b) of the Treaty on the Functioning of the European Union.5. If a State which has withdrawn from the Union asks to rejoin, its request shall be subject to the procedure referred to in Article 49."

12 See Marcelo Rebelo de Sousa, Comentário ao Artigo 2. ${ }^{\circ}$, Tratado de Lisboa - Anotado e Comentado (Coimbra: Almedina, 2012), 27-29.

${ }^{13}$ A. Tatham, "Don't Mention Divorce at the Wedding, Darling!' EU Accession and Withdrawal after Lisbon",in EU Law after Lisbon, ed. A. Biondi, P. Eeckhout and S. Ripley (Oxford: Oxford University 2012), 152.

${ }^{14}$ Maria Luísa Duarte talks about the existence of a "fundamental right to leave the European Union" in "A constituição europeia e os direitos de soberania dos Estados-Membros - elementos de um aparente paradoxo", O Direito 137 (2005, Vol. IV-V): 837 and seq.
} 
negotiate such an agreement pursuant to the principle of Sincere Cooperation, but this principle certainly does not oblige it to actually conclude an agreement.

Furthermore, nothing in the clause specifies its form or the timing, thus seemingly allowing the departing State discretion in this regard. But the discretion as to the timing for activating Article 50 TEU should not be unlimited, ${ }^{15}$ particularly in view of the principle of Sincere Cooperation under Article 4(3) TEU. ${ }^{16}$

In this circumstance, a Member State should not be allowed to use the exit threat to increase its negotiating leverage or to strengthen its future negotiating position, with clear prejudice to the functioning of the European Union.

Providing that this is the formal step that activates the whole exit procedure, the notification should be clear and there should be an unequivocal message from the State concerned that it intends to leave the European Union following an internal decision adopted to that effect.

It is important to notice that the notification, in itself, does not have a terminating effect, as made clear in Article 50(3) TEU which states that "the Treaties shall cease to apply to the State in question from the date of entry into force of the withdrawal agreement or, failing that, two years after the notification (...), unless the European Council, in agreement with the Member State concerned, unanimously decides to extend this period'.

The notification still has immediate legal implications, as paragraph four stipulates that for the purpose of Article 50 (2) and (3) TEU, "the member of the European Council or of the Council representing the withdrawing Member State shall not participate in the discussions of the European Council or Council or in European decisions concerning it'.

This suspension is understandable, considering the involvement of the European Council and of the Council in the withdrawal process: the European Council determines the guidelines for negotiating the withdrawal agreement with the State concerned, while the Council concludes the referred agreement.

Some authors argue that this suspension should be extended to all the withdrawing State representatives at the other EU institutions, such as the Commission, the European Parliament and the Court. ${ }^{17}$ Still, I believe that the solution enshrined in the Treaty is a more reasonable one.

But until the notification is formally and clearly submitted, and for so long as the Member State continues to fulfil all its membership obligations under the Treaties, the withdrawal process will not start.

Following the orientations of the European Council, the European Union agrees on the guidelines for negotiating an agreement with the State concerned, which is to be decided by the Council, by qualified majority, with the agreement of the European Parliament.

\footnotetext{
${ }^{15}$ The Heads of State or Government of the 27 European Union Member States pointed this out after the United Kingdom 2016 referendum, in the informal meeting that took place in Brussels, on the 29 June 2016, clarifying that while it was up to the British government to notify the European Council of the UK's intention to withdraw from the Union, this notification "should be done as quickly as possible [and] [t] here can be no negotiations of any kind before this notification has taken place".

${ }^{16}$ Alessandra Silveira sustains that "the doubts raised by Article 50 of the TEU must be solved in accordance with the principles of the EU law, in special the principle of loyalty [Article 4(3) of the TEU]", or principle of sincere cooperation, in "Brexit e o princípio federativo da lealdade europeia: considerações sobre o artigo 50. ${ }^{\circ}$ do Tratado da União Europeia”, UNIO E-book Volume I Workshops CEDU (2016): 331 et seq; about the principle of sincere cooperation see Fausto de Quadros comment to Article 4(3) TEU, in Tratado de Lisboa - anotado e comentado (Coimbra: Almedina, 2012), 35.

${ }^{17}$ See Michael Dougan, “The Treaty of Lisbon 2007: Winning minds, not hearts" Common Market Law Review, vol. 45, n. 3 (2008): 617-703.
} 
Also, the agreement shall be negotiated in accordance with Article 218(3) TFEU, that states as follows: "The Commission, or the High Representative of the Union for Foreign Affairs and Security Policy, where the agreement envisaged relates exclusively or principally to the common foreign and security policy, shall submit recommendations to the Council, which shall adopt a decision authorising the opening of negotiations and, depending on the subject of the agreement envisaged, nominating the Union negotiator or the head of the Union's negotiating team".

In fact, Article 50 TEU does not require a negotiated departure, ${ }^{18}$ and the negotiation only depends on the withdrawing state's willingness to discuss. Until effective departure, the Member State remains bound by the obligation of sincere cooperation and therefore to the duty to help the Union carry out its responsibilities, including that of negotiating an agreement.

It is also foreseen that should the former Member State intend to re-join the Union, it would have to apply on the basis of Article 49 TEU.

\section{Can a notification under Article 50 TEU be withdrawn?}

One thing is clear: Article 50 TEU remains soundless as to whether the withdrawing Member State may retract its notification to leave.

But how can we interpret this silence (among others) of Article 50 TEU?

On the one hand, paragraph 3 foresees that "the Treaties shall cease to apply to the State in question from the date of entry into force of the withdrawal agreement or, failing that, two years after the notification (...), unless the European Council, in agreement with the Member State concerned, unanimously decides to extend this period".

To start, we could interpret this provision in the sense that once the notification is given, there is no turning back and the Treaties will cease to apply to the State concerned, either upon the entry into force of the withdrawal agreement, or at the end of the two year period triggered by the notification, with the only possible change in the process being that the European Council and the Member State concerned change the time upon which the Treaties cease to apply, but not the withdrawal itself.

This interpretation would probably prevent a Member State from mistreating the procedure to find out what exit terms it could achieve whilst retaining the assurance of full membership if displeased with those terms.

In this context, the Miller Case ${ }^{19}$ concluded two things: first, a notice under Article 50(2) TEU cannot be withdrawn once it is given, and second, Article 50 TEU does not allow for a conditional notice to be given.

Lord Pannick sustained clearly that Article 50 TEU must exclude the right to retract a notification to leave because it makes " $n$ o mention of a power to withdraw". ${ }^{20}$

However, a different interpretation of this provision would allow the withdrawing Member State the possibility of holding up the withdrawal process following a sincere change of position of the State concerned. And in that case, the European Council and the Member State could extend the period long enough to establish the re-engagement within the integration process.

In fact, it is this last interpretation of Article $50 \mathrm{TEU}$ that is more in accordance with the nature of the reasoning method that implies reading terms in the text where

\footnotetext{
${ }^{18}$ Defending a unilateral right to exit the Union, see Hannes Hofmeister, "Should I Stay or Should I Go? - A Critical Analysis of the Right to Withdraw From the EU", European Law Journal 16, Issue 5 (September 2010): 589-592.

${ }^{19} \mathrm{R}$ (Miller) v. The Secretary of State for Exiting the European Union (2016) EWHC 2768 (Admin).

${ }^{20}$ Transcript dated of 13 October 2016, p.16.
} 
they are absent. Reasoning by implication is a well-established method of legal interpretation in general, and of European law more specifically.

We must remember that the CJEU has always employed this technique in its jurisprudence, a notable example being its ruling on the initial silence of the Treaties on the subject of fundamental rights and the Court activism in this matter. ${ }^{21}$

The CJEU has developed its own approach to the interpretation of the founding Treaties, concentrating on the "spirit, the general scheme and the wording" of the texts.

And as the Court sustained in the CILFIT judgement, "every provision of Community law must be placed in its context and interpreted in the light of the provisions of Community law as a whole, regard being had to the objectives thereof and to its state of evolution at the date on which the provision in question is to be applied."22

But Lord Pannick also argued that "the very possibility of a power to withdraw a notification would frustrate (...) Article 50(3), which sets out in the clearest possible terms, what the consequences are of giving the notification under Article 50(2)."

However I find in these assumptions the following difficulties.

First, Article 50(3) TEU provides that the withdrawal becomes effective two years after the notification to leave was given, should a withdrawal agreement not occur before that date. However, the European Council, acting with the agreement of the remaining Member States and the withdrawing Member State, may extend the two-year period indefinitely. In this case, the procedure laid down in Article 50(3) TEU does not have to end in the Member State's departure from the Union.

Second, contrary to what Lord Pannick pontificates, a power to revoke the notification would not frustrate the legal consequences provided by Article 50(3) TEU, since the only legal consequence that this Article imposes on the withdrawing Member State is this two-year delay before its notification takes effect. So the only thing that a power to revoke would frustrate is the withdrawal notification itself.

Additionally, we should note that the Supreme Court was not bound to decide on a point of European Union law, ex proprio motu here the parties have excluded that point from the scope of their dispute. Nor it was the Supreme Court bound to refer a question of European Union law to the CJEU for a preliminary ruling under Article 267 TFEU, when that question had no bearing on the outcome of the case submitted before it.

Hence, it is rather questionable whether the Supreme Court should have ruled alone that a withdrawal notice made under Article 50 TEU was irrevocable when ultimately, it is for the Court of Justice of the European Union to provide an authoritative interpretation of Article 50 TEU.

But proceedings have been initiated before the Irish Courts to obtain such a ruling by way of the Preliminary Reference Procedure. The proceedings pursue a referral to the CJEU on the question of whether the British government can unilaterally revoke Article 50 TEU once triggered, without the consent of all other 27 Member States. If a reference is really made to the CJEU, we will have the answer to the central question of this article.

Still, we cannot find legal barriers that would prevent a State from withdrawing

\footnotetext{
${ }^{21}$ About this activism, see Takis Tridimas, The General Principles of EU Law, (Oxford: University Press, 2005), 298 et seq.

${ }^{22}$ Judgment of the Court of 6 October 1982, Srl CILFIT and Lanificio di Gavardo SpA v Ministry of Health, Case 283/81, ECLI: EU:C:1982:335, at 20.
} 
a notification under Article 50 TEU. ${ }^{23}$ But I must admit that there is not, in the present context, an institutional or judicial precedent to guide the interpretation of Article 50 TEU and the provision is silent in this respect.

Nonetheless, while Article 50 TEU does not offer an express provision about reversing a withdrawal notification, it does not mean that it is excluding the possibility that such a power may be implied, or that this power could derive from general International law with the condition that it is compatible with the Treaties.

The preparatory work of the intergovernmental conference that drew up the Treaty of Lisbon is not in the public domain but Article 50 TEU reproduces Article 59 of the Draft Treaty Establishing a Constitution for Europe prepared by the European Convention.

The negotiating history of Article 59 shows that the right to withdraw from the Union was intended to be unilateral in character and the amendments endeavouring to bond this right to substantive conditions or to the successful conclusion of a withdrawal agreement were excluded.

The Praesidium of the European Convention explained that "it was felt that such an agreement should not constitute a condition for withdrawal so as not to void the concept of voluntary withdrawal of its substance", ${ }^{24}$ and recalled that; "procedure laid down in this provision draws on the procedure in the Vienna Convention on the Law of Treaties". ${ }^{25}$

Having in attention these preparatory work conclusions, as well as the Vienna Convention of the Law of Treaties 1969, I can only conclude that Article 50 TEU was intended to clearly recognise that the Member States have a unilateral right ${ }^{26}$ to withdraw from the Treaties and to regulate the procedure governing the exercise of this right.

Further, I cannot find evidence in the preparatory work conclusions to support the view that Article 50 TEU was intentionally drafted to exclude the right of a Member State to reverse its withdrawal notification.

Denying this right to the Member States not only contradicts the intentions of the Treaty drafters but also their understanding that Article 50 TEU draws upon the procedure set out in the Vienna Convention on the Law of the Treaties, namely Article 68 of this Convention.

Last but not least, these conclusions may raise procedural questions, namely, if there are any formal requirements that a Member State that intends to rescind its withdrawal notification must comply with.

Annulling a withdrawal notification is a formal Treaty act so it should be submitted in written form, just like the original notification itself.

Additionally, a withdrawing Member State doesn't have to justify the decision to leave the Union, so it should not have to justify its decision to revoke the withdrawal notification as well.

But having in consideration the principle of Sincere Cooperation, the withdrawing Member State should give some explanation regarding its decision, and the notice should be addressed to the European Council in its capacity as the recipient of the original notification under Article 50(2) TEU.

\footnotetext{
${ }^{23}$ See Paul Craig, "Brexit: A Drama in Six Acts", European Law Review 41 (2016, 447): 464-465; and Takis Tridimas, “Article 50: An Endgame without an End?”, King's Law Journal 27 (2016): 303-305.

${ }^{24}$ Praesidium, Title X: Union Membership, CONV 648/03 (2 April 2003), page 9.

${ }^{25}$ Praesidium, Title X: Union Membership (2 April 2003), page 9.

${ }^{26}$ Takis Tridimas, "Article 50: an endgame without an end", 301.
} 
In conclusion, the existence of this right to withdraw a notification submitted under Article 50 TEU is a matter of law, detached from political considerations. However, Member States that decide to trigger Article 50 TEU are always subject to the European Union law, and particularly to the principle of Sincere Cooperation that incorporates the principle of good faith.

There is no doubt that the withdrawal process disturbs the normal functioning of the European Union and it is an obligation of the withdrawing Member State to "facilitate the achievement of the Union's tasks and refrain from any measure which could jeopardise the attainment of the Union's objectives", as stated in Article 4(3) TEU. Consequently, if a Member State fails to comply with these principles using Article 50 TEU in an abusive way, it may open itself up to infringement proceedings under Article 258 TFEU.

\section{Conclusion}

To deny a Member State the right to revoke its unilateral decision to leave the European Union would be constitutionally incongruous and the European Union should accept a bona fide revocation of a notification within the two-year timeframe. If it occurs, its consequence is immediately halting the Article 50 clock.

The constitutional questions at stake in the process of withdrawing from the European Union are of the utmost importance for the Union's construction.

And it is the commitment to constitutional values that distinguishes the European Union from other international supranational organisations. These values will be put to the test during Brexit and other exits that might occur in the future.

But I believe that the recognition of a right to leave, as well as the respect for a right to stay, or to conscious return, can contribute to the pursuit of an "ever closer union among the peoples of Europe", precisely by making it possible for a State to step out of (or to conscious step back in), rather than hold up a further integration process. 